\title{
Effect of protein restriction on messenger RNA of insulin-like growth factor-I and insulin-like growth factor-binding proteins in liver of ovariectomized rats
}

\author{
Yusuke Higashi*, Asako Takenaka†, Shin-Ichiro Takahashi $\ddagger$ and Tadashi Noguchi§ \\ Laboratory of Nutritional Biochemistry, Department of Applied Biological Chemistry, \\ Graduate School of Agricultural and Life Sciences, University of Tokyo, Bunkyoku, Tokyo 113, Japan
}

(Received 19 August 1996-Revised 27 October 1997-Accepted 14 December 1997)

\begin{abstract}
Effects of dietary protein restriction and ovariectomy on plasma concentrations and hepatic messenger RNA (mRNA) of insulin-like growth factor-I (IGF-I) and insulin-like growth factor binding proteins (IGFBP) were investigated in young female rats. Ovariectomy increased plasma IGF-I concentration in rats fed on either a $50 \mathrm{~g}$ casein $/ \mathrm{kg}$ diet (protein-restricted diet) or a $200 \mathrm{~g}$ casein $/ \mathrm{kg}$ diet (control diet), but it increased IGF-I mRNA in liver only in the rats fed on the control diet. On the other hand, by Western ligand blot analysis, we observed that ovariectomy increased plasma IGFBP-3 concentration, and decreased plasma IGFBP-4 concentration. Ovariectomy did not affect IGFBP-1 and IGFBP-2 mRNA in liver, but dietary protein restriction significantly increased them, which may correspond to their plasma concentrations. The present results show that ovarian hormones and dietary protein content affect the plasma concentrations of IGF-I, IGFBP-3 and IGFBP-4 and hepatic mRNA of IGF-I, IGFBP-1, IGFBP-2, IGFBP-3 and IGFBP-4 in different manners.
\end{abstract}

Insulin-like growth factor-I: Insulin-like growth factor-binding proteins: Protein restriction: Ovariectomy

In a preceding paper (Higashi et al. 1996) we showed that femoral messenger RNA (mRNA) of bone matrix proteins and growth factors, which play important roles in bone formation, are affected by both dietary protein content and ovariectomy. In particular, the mRNA of insulin-like growth factor (IGF)-I, IGF-II and their binding proteins reacted to ovariectomy and protein restriction.

The quantity and the nutritional quality of dietary proteins are well known to affect plasma IGF-I concentration greatly (Prewitt et al. 1982; Isley et al. 1983; Takahashi et al. 1990). Concomitantly IGF-I mRNA in liver is affected greatly as well (Moats-Staats et al. 1989; Thissen et al. 1991a; Miura et al. 1992). We and others have suggested that IGF-I regulates body protein metabolism in response to dietary proteins. On the other hand, IGF-I and IGF-II have been shown to circulate in blood complexed with specific proteins referred to as IGF-binding proteins (IGFBP) (Cohen \& Nissley, 1975; Hintz \& Liu,
1977). Six distinct IGFBP from man and the rat have already been purified and their complementary DNA (cDNA) have been cloned (Martin \& Baxter, 1986; Brinkman et al. 1988; Brown et al. 1989; Mohan et al. 1989; Shimasaki et al. 1990, 1991 $a, b$ ). These IGFBP, in purified or recombinant form, greatly modulate the biological activity of IGF-I or IGF-II. We and others (Orlowski et al. 1990; Murphy et al. 1991; Thissen et al. $1991 b$; Umezawa et al. 1991) have reported that plasma concentrations of IGFBP are also affected significantly by dietary factors. Therefore, the effect of IGF-I on the target tissues must be regulated in a complex manner through the changes in the concentration of IGF-I itself and changes in the concentrations of IGFBP.

The importance of local synthesis of IGF and IGFBP for cell proliferation and cell differentiation has repeatedly been stressed by many investigators (Murphy, 1991; Baylink et al. 1993; Hammond et al. 1993; Nestler, 1993;

\footnotetext{
Abbreviations: BSA, bovine serum albumin; cDNA, complementary DNA; IGF-I, insulin-like growth factor-I; IGFBP, insulin-like growth factor-binding proteins; mRNA, messenger RNA.

* Present address: Department of Microbiology and Molecular Pathology, Faculty of Pharmaceutical Sciences, Teikyo University, Sagamiko, Kanagawa 199-01, Japan.

† Present address: Department of Bioproduction, Faculty of Agriculture, Yamagata University, 1-23 Wakaba-cho, Tsuruoka-shi, Yamagata 997, Japan. * Present address: Department of Applied Animal Sciences, Graduate School of Agricultural and Life Sciences, University of Tokyo, Tokyo 113, Japan. $\S$ Corresponding author: Dr Tadashi Noguchi, fax +8133812 0544, email noguchi@eiyo.m.u-tokyo.ac.jp
} 
Vinik et al. 1993). In the preceding paper, we showed the effect of dietary protein restriction and ovariectomy on the mRNA of IGF and IGFBP in femur, and mentioned the biological significance of IGF and IGFBP which are produced locally. However, as IGF-I and some IGFBP are primarily produced by liver and secreted into the bloodstream, it is possible that these proteins can regulate bone metabolism. The possible endocrine role of IGF and IGFBP must be determined. In the present paper, we report the changes in the plasma concentrations of IGF and IGFBP and their mRNA levels in liver under protein restriction and ovariectomy.

\section{Materials and methods}

\section{Materials}

Human recombinant IGF-I and anti-human IGF-I antibody were kindly donated by Dr M. Niwa, Fujisawa Pharmaceutical Co. (Osaka, Japan). Normal rabbit serum and anti-rabbit $\gamma$-globulin goat antibody were obtained from Daiichi Radioisotope Laboratory (Tokyo, Japan). ${ }^{125}$ I-labelled IGF-I was prepared from $\mathrm{Na}^{125} \mathrm{I}$ and IGF-I according to a mild chloramine $\mathrm{T}$ method as modified by Umezawa et al. (1991). The cDNA of rat IGF-I, IGFBP-1 and IGFBP-3 were prepared as we reported previously (Kato et al. 1990; Takenaka et al. 1991, 1993). Rat IGFBP-2 cDNA and IGFBP-4 cDNA were kindly given by Dr A.J. D'Ercole, The University of North Carolina (NC, USA). Other chemicals were of the reagent grade available commercially.

\section{Animals}

Animals were the same as those in the preceding paper (Higashi et al. 1996). Briefly, 7-week-old female Wistarstrain rats were obtained from Charles River Japan (Kanagawa, Japan) and fed on a control diet containing $200 \mathrm{~g}$ casein $/ \mathrm{kg}$ diet (200C diet, Higashi et al. 1996) until the operation. The rats were given the diet from 09.00 to 17.00 hours and water ad libitum. After $4 \mathrm{~d}$, the rats were either ovariectomized bilaterally or sham-operated, and then were divided into two dietary groups; (A) those fed on the control diet (initial body weight: sham-operated rats, 193 (SE 2) g, $n$ 5; ovariectomized rats, 189 (SE 2) g, $n$ 5) and (B) those fed on a $50 \mathrm{~g}$ casein $/ \mathrm{kg}$ diet $(50 \mathrm{C}$ diet, Higashi et al. 1996; protein-restricted diet) (initial body weight: shamoperated rats, 186 (SE 5) g, $n$ 5; ovariectomized rats, 190 (SE $5) \mathrm{g}, n 5$ ). The food intake of the control group was paired with that of the protein-restricted group of the same operation, i.e. the food intake of the ovariectomized or sham-operated rats fed on the $50 \mathrm{C}$ diet was measured individually and the same amount of the $200 \mathrm{C}$ diet was fed to the paired rats on the next day. At 3 weeks later the rats were fed at 10.00 hours and killed at 11.30 hours by decapitation under pentobarbital anaesthesia $(50 \mathrm{mg}$ pentobarbital $/ \mathrm{kg}$ body weight). Arterial blood was collected in $\mathrm{Na}_{2}$ EDTA and plasma was prepared as described previously (Takahashi et al. 1990). The plasma was kept at $-20^{\circ}$ until analysis. The liver was quickly excised, frozen in liquid $\mathrm{N}_{2}$ and kept at $-80^{\circ}$ until RNA preparation.

\section{IGF-I radioimmunoassay}

The total IGF-I concentration was determined after treatment of the plasma with an acid-ethanol mixture as described previously (Takahashi et al. 1990), because, in these experiments, plasma concentration of total IGF-I measured after acid-ethanol treatment was not significantly different from total IGF-I concentration measured after acid-gel permeation chromatography according to the method of Crawford et al. (1992). Radioimmunoassay for IGF-I was performed as follows. Samples $(0.1 \mathrm{ml})$ after acid-ethanol treatment were mixed with $0.1 \mathrm{ml}$ IGF-I antibody solution and $0.5 \mathrm{ml}$ buffer solution for radioimmunoassay (Dulbecco's phosphate-buffered saline solution consisting of $(\mathrm{g} / \mathrm{l}): \mathrm{NaCl} 8, \mathrm{KCl} 0.2, \mathrm{Na}_{2} \mathrm{HPO}_{4} 1.15$ and $\mathrm{NaH}_{2} \mathrm{PO}_{4} 0 \cdot 2$, supplemented with $25 \mathrm{mM}$-EDTA and $50 \mathrm{~g}$ bovine serum albumin (BSA)/1). This solution was kept at $4^{\circ}$ for $24 \mathrm{~h}$, then $0.1 \mathrm{ml}$ each of rabbit serum (fifty times diluted) and anti-rabbit $\gamma$-globulin goat antibody (ten times diluted) were added to the solution. This mixture was allowed to stand at $4^{\circ}$ for $2-3 \mathrm{~h}$ and then centrifuged at $2000 \mathrm{~g}$ for $30 \mathrm{~min}$ at $4^{\circ}$. The radioactivity in the precipitate was counted with a $\gamma$-counter (Aloka Auto Well Gamma System ARC-500, Aloka, Tokyo, Japan). Recombinant human IGF-I was used as the standard for IGF-I determination.

\section{Total RNA preparation}

The total RNA was prepared from liver according to the method described previously (Miura et al. 1992).

\section{Northern hybridization analysis}

The methods used to label probes and perform Northern hybridization were as described previously and in the preceding paper (Miura et al. 1992; Higashi et al. 1996).

\section{Western ligand blot analysis of IGFBP in plasma}

Plasma concentrations of IGFBP were determined by Western ligand blot analysis by the method of Umezawa et al. (1991). At the time of analysis the plasma was mixed with an equal volume of $2 \times$ concentrated Laemmli's sample buffer solution (the original $1 \times$ Laemmli's solution contained $50 \mathrm{~g}$ SDS $/ 1,100 \mathrm{ml}$ glycerol $/ 1,0.06 \mathrm{M}$-Tris- $\mathrm{HCl}$ $\mathrm{pH} 6.8$ and $0.2 \mathrm{ml}$ bromophenol blue/1) and heated at $65^{\circ}$ for $15 \mathrm{~min}$. This sample was electrophoresed on $125 \mathrm{~g} / \mathrm{l}$ polyacrylamide gel containing $1 \mathrm{~g} \mathrm{SDS} / 1$ without reducing agents. After electrophoresis, proteins were transblotted to a nitrocellulose filter in the transfer buffer solution $(2.9 \mathrm{~g} / 1$ Tris, $14.5 \mathrm{~g} / 1$ glycine in $200 \mathrm{ml} / 1$ methanol, $\mathrm{pH} 8.3$ ) at $200 \mathrm{~mA}$ for $4.5 \mathrm{~h}$ using the transblot system (Bio-Rad, CA, USA). The filter was soaked in $30 \mathrm{ml} / 1 \mathrm{NP}-40$ saline solution (saline solution consists of $0.15 \mathrm{M}-\mathrm{NaCl}$ and 0.01 $\mathrm{M}$-Tris- $\mathrm{HCl}, \mathrm{pH} \mathrm{7.4)}$ for $30 \mathrm{~min}$ and further blocked in $30 \mathrm{~g} / \mathrm{l} \mathrm{BSA}$ in saline solution at $4^{\circ}$ for $12 \mathrm{~h}$. The filter was washed by shaking in $1 \mathrm{ml} / 1$ Tween 20 in saline at $4^{\circ}$ for 10 min. Then the filter was put in $1 \mathrm{ml} / 1$ Tween $20,40 \mathrm{~g} / 1$ BSA with [ ${ }^{125}$ I]IGF-I $(4000 \mathrm{cpm})$ in saline at $4^{\circ}$ for $10 \mathrm{~h}$. 
Table 1. Body-weight gain, food intake and plasma concentrations of insulin-like growth factor-I (IGF-I) and IGF-binding proteins (IGFBP) in

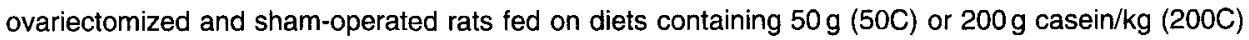

(Mean values for five rats with their pooled standard error)

\begin{tabular}{|c|c|c|c|c|c|c|c|c|}
\hline \multirow{2}{*}{$\begin{array}{l}\text { Diet... } \\
\text { Treatment... }\end{array}$} & \multicolumn{2}{|c|}{$50 \mathrm{C}$} & \multicolumn{2}{|c|}{$200 \mathrm{C}$} & \multirow[b]{2}{*}{ SEM } & \multicolumn{3}{|c|}{ Statistical significance of effect of: } \\
\hline & Sham-operated & Ovariectomized & Sham-operated & Ovariectomized & & Diet (D) & Ovariectomy $(\mathrm{O})$ & $O \times D$ \\
\hline Body-wt gain $(g)$ & $40 \dagger$ & 60 接 & 49 & $75 \$$ & 5 & $*$ & $\star * *$ & NS \\
\hline Food intake $(\mathrm{g} / \mathrm{d})$ & 14.9 & $17.1 \pm t$ & 14.9 & $17.1+1$ & 0.6 & NS & ** & NS \\
\hline Total IGF-I (ng/ml) & 8608 & $10573 \div$ & 9820 & 11256 & 629 & NS & * & NS \\
\hline IGFBP-3\& & 90.3 & $106.9 \ddagger$ & $100 \cdot 0$ & $135.5 \ddagger$ & 11.1 & NS & * & NS \\
\hline IGFBP-4\$ & 95.0 & $62 \cdot 3_{+}^{+}$ & $100 \cdot 0$ & $74.6_{+}^{+}$ & 10.8 & NS & * & NS \\
\hline
\end{tabular}

${ }^{*} P<0.05,{ }^{* *} P<0.01$ by two-way ANOVA.

Mean values were significantly different from those for the $200 \mathrm{C}$ group: $\dagger P<0.05$ (Tukey's method).

Mean values were significantly different from those for the sham-operated group: $\ddagger P<0.05$, $\neq+P<0.01$ (Tukey's method).

$\S$ The IGFBP levels were determined by quantification of the Western ligand blotting shown in Fig. 2 by a Fujix Bas 2000 system (Fuji Film Co., Kanagawa, Japan). Results are expressed as the relative radioactivity of the bands, taking the mean of the sham-operated $200 \mathrm{C}$ group as 100 .

After the filter was washed twice by shaking in $1 \mathrm{ml} / 1$ Tween 20 in saline at $4^{\circ}$ for $10 \mathrm{~min}$ and twice in saline, it was air-dried and autoradiographed. The radioactivity of the filter was also determined by Fujix Bas 2000 Bio Image Analyzer (Fuji Film Co., Tokyo, Japan), and the results were expressed as the relative radioactivity of the bands taking the mean of the sham-operated $200 \mathrm{C}$ group as 100 .

\section{Statistical analysis}

The results were analysed statistically by two-way ANOVA (Snedecor \& Cochran, 1967). When the difference among the groups was significant, Tukey's least significant difference method was employed to show the difference among the mean values.

\section{Results \\ The effects of protein restriction and ovariectomy on plasma IGF-I concentration and on the gene expression of IGF-I in liver}

Table 1 shows the plasma IGF-I concentration in the protein-restricted and ovariectomized rats. Ovariectomy significantly increased the plasma concentration of total IGF-I after acid-ethanol extraction; on the other hand, protein restriction did not affect it. The total IGF-I concentration was correlated with the changes in bodyweight gain $(r 0.457, P<0.05)$.

Fig. 1 and Table 2 show the changes in IGF-I mRNA content in liver of the ovariectomized and sham-operated rats fed on the two diets. The effects of ovariectomy and protein restriction interacted significantly, because ovariectomy increased IGF-I mRNA in liver in the $200 \mathrm{C}$ diet groups, but not in the $50 \mathrm{C}$ diet groups. This tendency was observed equally for mRNA for all four species of IGF-I (Fig. 1).

\section{The effects of protein restriction and ovariectomy on plasma IGFBP concentration and on the gene expression of $I G F B P$ in liver}

Fig. 2 and Table 1 show the effect of ovariectomy and/or protein restriction on the plasma concentrations of IGFBP in the rats determined by Western ligand blot analysis. Ovariectomy showed contrasting effects on IGFBP-3 and IGFBP-4, as plasma IGFBP-3 concentration was increased, but IGFBP-4 concentration was decreased by ovariectomy. On the other hand, protein restriction had no effect on these concentrations (Fig. 2 and Table 1).

Fig. 3 and Table 2 show the changes in IGFBP mRNA in liver. Ovariectomy caused variable effects on IGFBP-1 mRNA content, increasing the IGFBP-1 mRNA in three of five rats fed on the $200 \mathrm{C}$ diet in this study. Dietary protein restriction increased IGFBP-1 mRNA content when the rats were sham-operated, but not when they were ovariectomized (Table 2). Ovariectomy did not show any significant effect on IGFBP-2 and IGFBP-3 mRNA in liver; on the other hand, protein restriction significantly increased IGFBP-2 mRNA, and decreased IGFBP-3 mRNA content, and this effect interacted with that of ovariectomy, resulting in decreased mRNA content only in ovariectomized rats fed on the $200 \mathrm{C}$ diet.

\section{Discussion}

In the present studies we showed that ovariectomy and dietary protein restriction affected plasma concentrations of IGF-I and some IGFBP, and their corresponding mRNA in liver in different ways.

Ovariectomy increased the plasma IGF-I concentration and this was correlated with the body-weight changes as well as IGF-I mRNA contents in liver (Tables 1 and 2). These results suggest that ovarian hormone deficiency leads to animal growth through increasing hepatic IGF-I synthesis. However, we observed increased food consumption in ovariectomized rats in this experiment. Since not only the quality, but also the quantity of protein is known to influence the plasma IGF-I concentration (Takahashi et al. 1990; for review, see Thissen et al. 1994), we could not rule out the possibility that these changes in plasma IGF-I concentration and hepatic IGF-I mRNA contents were explained by food consumption. Aerssens et al. (1993) and Sato et al. (1993) also reported that ovariectomy increased the plasma IGF-I concentration. In the experiment of Sato et al. (1993) the food consumption of ovariectomized rats was matched with that of sham-operated rats. Thus, the 


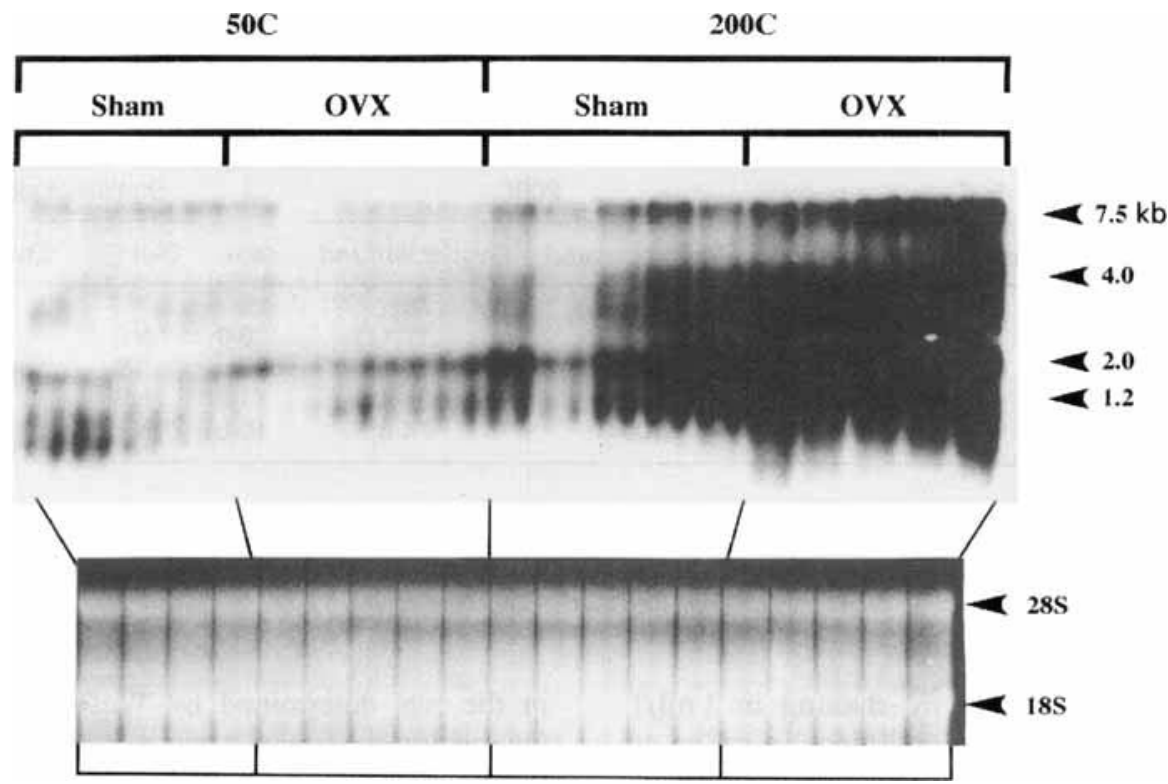

Fig. 1. Northern blot analysis of insulin-like growth factor-I messenger RNA in liver from shamoperated (Sham) and ovariectomized (OVX) rats fed on diets containing 50 (50C) or $200 \mathrm{~g}$ casein $/ \mathrm{kg}(200 \mathrm{C})$ for $7 \mathrm{~d}$. For details of procedures, see pp. 448-449. A $30 \mu \mathrm{g}$ portion of total RNA from one rat was applied to each lane. The positions of molecular markers are indicated on the right. Bands of ribosomal RNA stained by ethidium bromide (bottom, sizes shown on the right) demonstrate equal amounts of RNA per lane.

increased plasma IGF-I concentration in the ovariectomized rats could not have been the result of increased food consumption, but must have been related to oestrogen or ovarian hormone deficiency. From these results, we assume
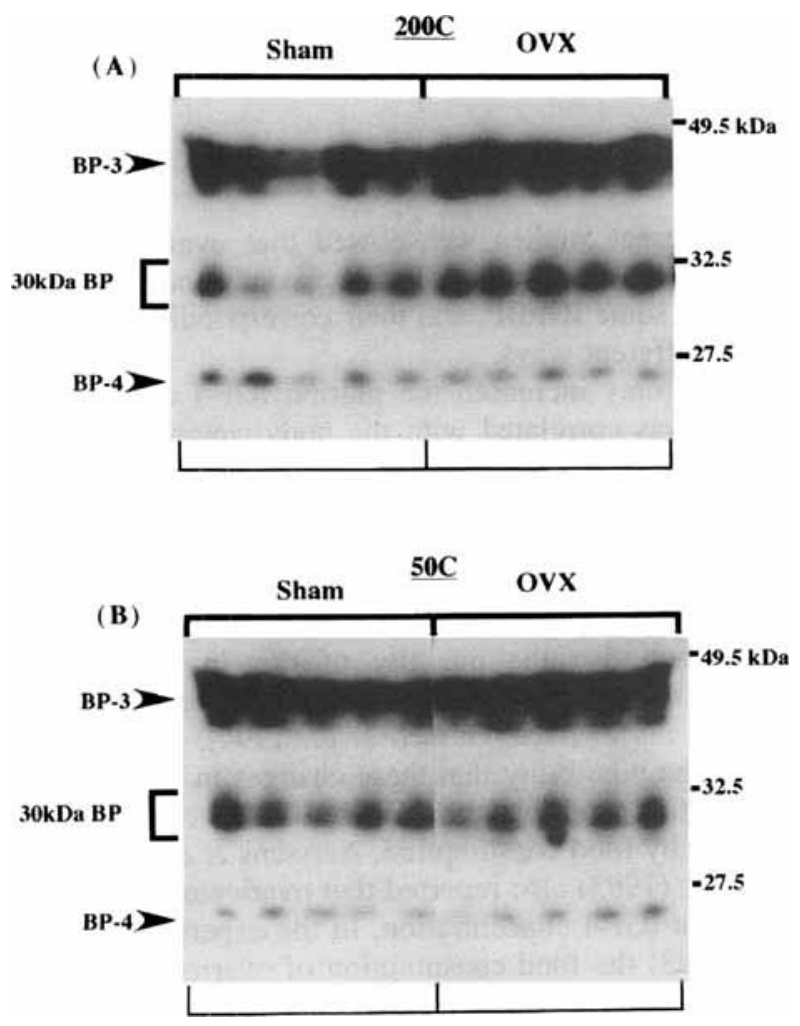

that ovarian hormone deficiency directly induces hepatic gene expression of IGF-I, thereby inducing an increase in IGF-I production in liver.

Furthermore, we found that the effect of protein restriction interacted with that of ovariectomy on the IGF-I mRNA content in liver. Dietary protein restriction decreased the mRNA content as previously reported (Thissen et al. 1994), and ovariectomy increased the mRNA content of the $200 \mathrm{C}$ diet groups, but not that of $50 \mathrm{C}$ diet groups. These results suggest that oestrogen suppresses gene expression of IGF-I in liver, but, when the dietary protein is restricted, this suppressive effect of oestrogen is completely abolished. In liver, Murphy \& Friesen (1988) and Krattenmacher et al. (1994) reported that chronic oestrogen treatment reduced the IGF-I mRNA content. They concluded that the oestrogen effect was indirect and might be caused by oestrogen depression of growth hormone-dependent IGF-I production in liver. These results are comparable to our observation that chronic oestrogen deficiency increased the hepatic IGF-I mRNA content. We observed that ovariectomy did not influence the IGF-I mRNA when the protein intake was restricted. This observation, together with the finding that

Fig. 2. Western ligand blot analysis of insulin-like growth factorbinding proteins in plasma from sham-operated (Sham) and ovariectomized (OVX) rats fed on diets containing (A) $50 \mathrm{~g}$ casein/ $\mathrm{kg}(50 \mathrm{C})$ and (B) $200 \mathrm{~g}$ casein/ $\mathrm{kg}(200 \mathrm{C})$. Plasma $(5 \mu \mathrm{l})$ was subjected to SDS-PAGE and after electrophoresis proteins were transferred to a nitrocellulose filter. The proteins which bound $\left.\left[{ }^{125}\right]\right]$ insulin-like growth factor-I were defected by a Fujix Bas 2000 system (Fuji Film Co., Kanagawa, Japan). Each lane corresponds to the plasma from one rat. 
Table 2. IGF-binding protein (IGFBP) messenger RNA (mRNA) contents $\ddagger$ in the livers of ovariectomized and sham-operated rats fed on diets containing $50(50 \mathrm{C})$ or $200 \mathrm{~g}$ casein $/ \mathrm{kg}(200 \mathrm{C})$

(Mean values for five rats with their pooled standard error)

\begin{tabular}{|c|c|c|c|c|c|c|c|c|}
\hline \multirow{2}{*}{$\begin{array}{l}\text { Diet... } \\
\text { Treatment... }\end{array}$} & \multicolumn{2}{|c|}{$50 \mathrm{C}$} & \multicolumn{2}{|c|}{$200 \mathrm{C}$} & \multirow[b]{2}{*}{ SEM } & \multicolumn{3}{|c|}{ Statistical significance of effect of: } \\
\hline & Sham-operated & Ovariectomized & Sham-operated & Ovariectomized & & Diet (D) & Ovariectomy $(\mathrm{O})$ & $O \times D$ \\
\hline $\begin{array}{l}\text { IGFBP-1 mRNA } \\
\text { IGFBP-2 mRNA } \\
\text { IGFBP-3 mRNA } \\
\text { IGFBP-4 mRNA }\end{array}$ & $\begin{array}{r}1499 \cdot 9^{a} \\
303.2 \dagger \\
60.8 \dagger \\
86.9^{A B}\end{array}$ & $\begin{array}{c}988.0^{\mathrm{ab}} \\
450.9^{\dagger} \\
74.6 \dagger \\
94.7^{A}\end{array}$ & $\begin{array}{l}100 \cdot 0^{\mathrm{C}} \\
100 \cdot 0 \\
100 \cdot 0^{\mathrm{A}} \\
100 \cdot 0^{\mathrm{A}}\end{array}$ & $\begin{array}{c}540.9^{\mathrm{bc}} \\
180.6 \\
124.6 \\
58.0^{\mathrm{B}}\end{array}$ & $\begin{array}{r}165.9 \\
91.7 \\
10.8 \\
5.7\end{array}$ & $\begin{array}{c}* \star \\
\text { * } \\
\text { NA } \\
\text { NS }\end{array}$ & $\begin{array}{l}\text { NS } \\
\text { NS } \\
\text { NS } \\
*\end{array}$ & $\begin{array}{l}* \\
\text { NS } \\
\text { NS } \\
* *\end{array}$ \\
\hline
\end{tabular}

a,b,c,A,B,C Mean values within a row not sharing a common superscript letter were significantly different: ${ }^{a}, b, c P<0,05, A, B, C P<0.01$ (Tukey's method).

${ }^{*} P<0.05,{ }^{* \star} P<0.01$ by two-way ANOVA. Mean values were significantly different from those for the $200 \mathrm{C}$ group. $\dagger P<0.05,+\dagger P<0.01$.

+ The mRNA levels were determined by quantification of the Northern blot analyses shown in Figs. 1 and 3 using a Fujix Bas 2000 system (Fuji Film Co., Kanagawa, Japan). Results are expressed as relative radioactivity of the bands, taking the mean of the sham-operated $200 \mathrm{C}$ group as 100 .

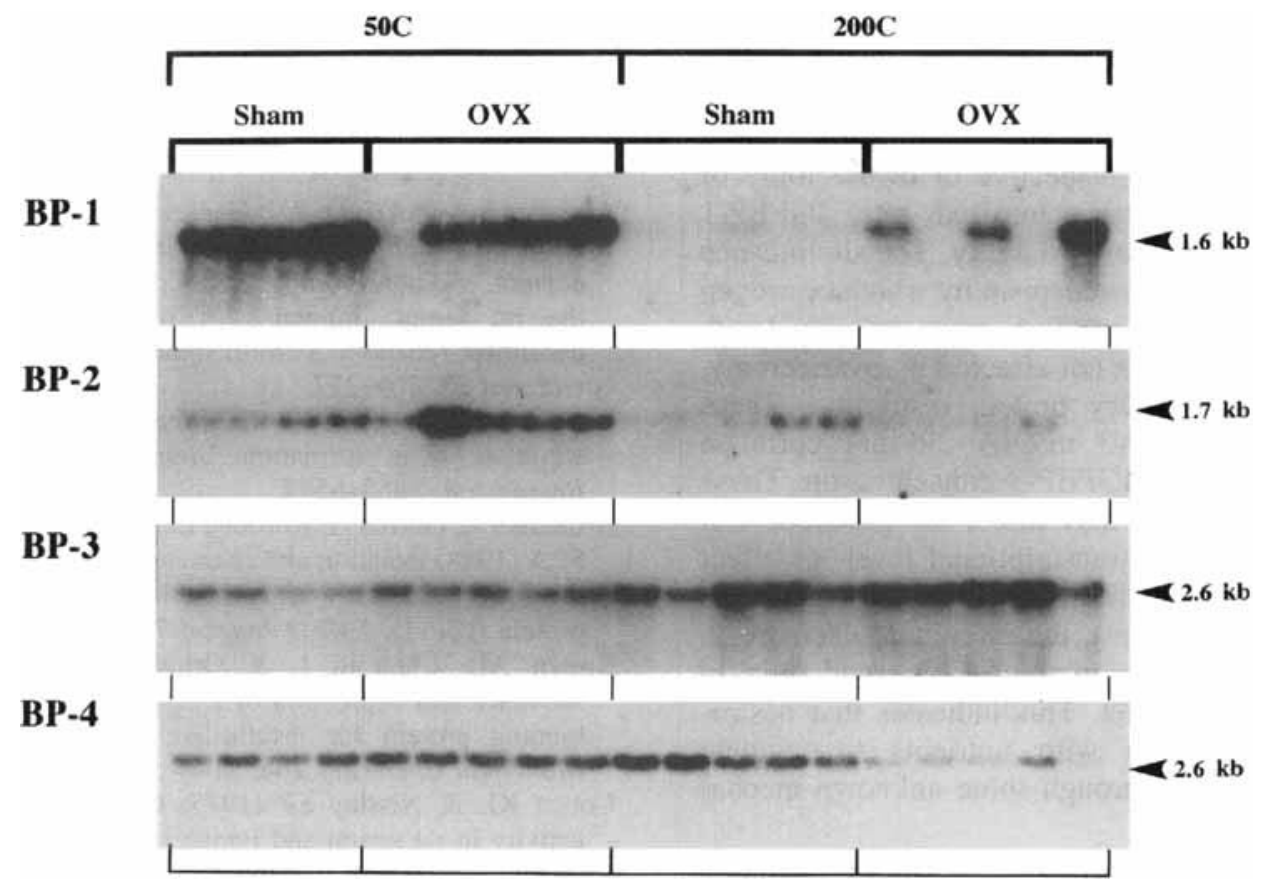

Fig. 3. Northern blot analysis of insulin-like growth factor-binding protein (BP) messenger RNA in liver from sham-operated (Sham) and ovariectomized (OVX) rats fed on diets containing $50(50 \mathrm{C})$ or $200 \mathrm{~g}$

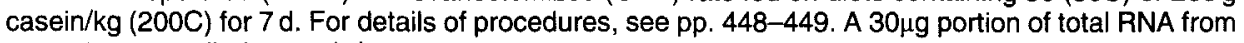
one rat was applied to each lane.

protein malnutrition impaired growth hormone dependent IGF-I production by a post-growth hormone receptor event (Maes et al. 1988), raises the possibility that a decrease in IGF-I gene expression, induced either by high levels of oestrogen or low dietary protein, is a growth hormonemediated occurrence.

Despite these observations about the effect of protein restriction on IGF-I mRNA, the plasma IGF-I concentration was not significantly affected by protein restriction. We and others have already shown that protein malnutrition causes a decrease in liver IGF-I mRNA (Moats-Staats et al. 1989; Thissen et al. 1991a; Muira et al. 1992). The finding that plasma IGF-I concentration did not correlate with the hepatic IGF-I mRNA may be due to a change in translation of the mRNA, or to altered IGFBP profile.
The biological activity and the half-life of IGF is believed to be modulated by IGFBP. In some cases, ovariectomy and dietary protein restriction changed the plasma concentrations of IGFBP which were determined by Western ligand blotting (Fig. 2 and Table 1). Ovariectomy increased the plasma IGFBP-3 concentration. The bands at about $30 \mathrm{kDa}$ in Western ligand blotting consisted of at least five IGFBP including IGFBP-1, IGFBP-2, glycosylated IGFBP-4, IGFBP-5 and IGFBP-6. Therefore, it is impossible to say which IGFBP at about $30 \mathrm{kDa}$ was affected by protein restriction and ovariectomy. Nonglycosylated IGFBP-4 at $20 \mathrm{kDa}$ was clearly separated from the IGFBP at about $30 \mathrm{kDa}$ and ovariectomy decreased the plasma concentration of non-glycosylated IGFBP-4. Kalu et al. (1994) showed that ovariectomy 
increased, low-dose $17 \beta$-oestradiol restored, and high-dose $17 \beta$-oestradiol reduced serum IGFBP-3 concentrations compared with sham-operated rats, and these treatments did not affect serum levels of other small IGFBP. Our results for IGFBP-3 are well in accordance with their reports. From the results for plasma IGFBP-3 and IGF-I (see p. 449), we conclude that plasma IGFBP-3 concentration is well correlated with plasma IGF-I level through some mechanism, such as formation of the complex of IGFI, IGFBP-3 and the acid labile subunit, possibly to prolong the half-life of both IGF-I and IGFBP-3 in plasma. Furthermore we showed that ovarian hormone deficiency could influence plasma IGFBP-4 concentration. These results suggest that plasma IGF-I which is bound to IGFBP-3 increased and that bound to IGFBP-4 decreased under oestrogen deficiency.

We also measured the mRNA content of each IGFBP in liver to examine the effects of ovariectomy and/or dietary protein restriction. The levels of liver IGFBP-1 and IGFBP-2 mRNA increased significantly under dietary protein restriction, irrespective of ovariectomy or sham-operation. Among ovariectomized rats, IGFBP-1 mRNA contents showed great variability. The significance of this observation, and the mechanism by which oestrogen regulates IGFBP-1 gene expression, must be elucidated. IGFBP-3 mRNA content was not affected by ovariectomy, but was decreased by dietary protein restriction. These changes in hepatic IGFBP-3 mRNA did not correlate with the change in plasma IGFBP-3 concentration. These results show that oestrogen may affect the production of IGFBP-3 in liver at a post-transcriptional level, or affect its production in organs other than liver, or change its stability in plasma. In contrast, the prominent decrease in IGFBP-4 mRNA content in liver was observed only in the rats fed on the $200 \mathrm{C}$ diet. This indicates that oestrogen works in cooperation with nutrients to regulate IGFBP-4 gene expression through some unknown mechanisms.

IGF-I and IGFBP are locally produced in various tissues and organs, and the importance of their local action has been stressed by many investigators (Jones \& Clemmons, 1995). For example, in the uterus, oestrogen-dependent production of IGF-I is known to be important to maintain functions of this organ (Murphy, 1991). In bone, we reported that ovarian hormone deficiency and dietary proteins affected IGF-I and IGFBP gene expression, and that they could regulate bone metabolism (Higashi et al. 1996). On the other hand, endocrine IGF-I and IGFBP are also shown to regulate metabolism in various tissues and organs. For example, plasma IGF-I concentration correlates well with the rate of whole-body protein synthesis (Nam et al. 1990). From these results and those from previous studies showing that ovariectomy induced an increase in bone turnover, we assume that increasing formation of IGFI and IGFBP-3 complex as well as decreasing IGFBP-4 in plasma, caused an increase in IGF-I bioactivity under oestrogen or ovarian hormone deficiency. On the other hand, IGF-I bioactivity is supposed to be suppressed by decreasing formation of IGF-I and IGFBP-3 complex as well as increasing plasma IGFBP-1 and IGFBP-2 under protein malnutrition.
In the present study we investigated the effects of ovariectomy and dietary protein restriction on the plasma concentrations of IGF-I and IGFBP, and the mRNA contents of IGF-I and IGFBP in liver. From these observations we suggest that plasma IGF and IGFBP, whose production is affected by oestrogens or ovarian hormones and dietary proteins, play very important roles in the regulation of animal growth and metabolism.

\section{Acknowledgements}

The authors thank Dr M. Niwa, Fujisawa Pharmaceutical Co. (Osaka, Japan) for donating human recombinant IGF-I and anti-IGF-I antibody, and Dr A.J. D'Ercole, University of North Carolina (NC, USA) for providing IGFBP-2 and IGFBP-4 cDNA.

\section{References}

Aerssens J, Audekercke RV, Geusens P, Schot LPC, Osman AAH \& Dequeker J (1993) Mechanical properties, bone mineral content, and bone composition (collagen, osteocalcin, IGF-I) of the rat femur: influence of ovariectomy and nandrolone decanoate (anabolic steroid) treatment. Calcified Tissue International 53, 269-277.

Baylink DJ, Finkelman RD \& Mohan S (1993) Growth factors to stimulate bone formation. Journal of Bone and Mineral Research 8, S565-S572.

Brinkman A, Goffen G, Kortleve DJ, Geurts van Kessel A \& Drop SLA (1988) Isolation and characterization of a cDNA encoding the low molecular weight insulin-like growth factor binding protein (IBP-1). EMBO Journal 7, 2417-2423.

Brown AL, Chiarotti L \& Orlowski CC (1989) Nucleotide sequence and expression of a cDNA close encoding a fetal rat binding protein for insulin-like growth factors. Joumal of Biological Chemistry 264, 5148-5154.

Cohen KL \& Nissley SP (1975) Comparison of somatomedin activity in rat serum and lymph. Endocrinology 97 654-658.

Crawford BA, Martin JL, Howe CJ, Handelsman DJ \& Baxter RC (1992) Comparison of extraction methods for insulin-like growth factor-I in rat serum. Journal of Endocrinology 134 169-176.

Hammond JM, Samaras SE, Grimes R, Leighton J, Barber J, Canning SF \& Guthirie HD (1993) The role of insulin-like growth factors and epidermal growth factor-related peptides in intraovarian regulation in the pig ovary. Journal of Reproduction and Fertility 48, Suppl., 117-125.

Higashi Y, Takenaka A, Takahashi S-I \& Noguchi T (1996) Effect of protein restriction on the messenger RNA contents of bonematrix proteins, insulin-like growth factors and insulin-like growth factor binding proteins in femur of ovariectomized rats. British Journal of Nutrition 75, 811-823.

Hinz RL \& Liu F (1977) Demonstration of specific plasma protein binding sites for somatomedin. Journal of Clinical Endocrinology and Metabolism 45, 988-995.

Isley WL, Underwood LE \& Clemmons DR (1983) Dietary components that regulate serum somatomedin-C concentrations in humans. Journal of Clinical Investigation 71, 175-182.

Jones JI \& Clemmons DR (1995) Insulin-like growth factors and their binding proteins: biological actions. Endocrine Reviews 16, 3-33.

Kalu DU, Arijmandi BH, Liu C-C, Salih MA \& Birnbaum RS (1994) Effects of ovariectomy and estrogen on the serum levels 
of insulin-like growth factor-I and insulin-like growth factor binding protein-3. Bone and Mineral 25, 135-148.

Kato H, Takenaka A, Miura Y, Nishiyama M \& Noguchi T (1990) Evidence of introduction by molecular cloning of artificial inverted sequence at the $5^{\prime}$ terminus of the sense strand of rat insulin-like growth factor-I cDNA. Agricultural Biological Chemistry 54, 2225-2230.

Krattenmacher R, Knauthe R, Parczyk K, Walker A, Hilgenfeldt U \& Fritzemeier KH (1994) Estrogen action on hepatic synthesis of angiotensinogen and IGF-I: direct and indirect estrogen effects. Journal of Steroid Biochemistry and Molecular Biology 48, 207-214.

Maes M, Amand Y, Underwood LE, Maiter D \& Ketelslegers JM (1988) Decreased serum insulin-like growth factor-I response to growth hormone in hypophysectomized rats fed a low protein diet: evidence for a post receptor defect. Acta Endocrinologica (Copenhagen) 117, 320-326.

Martin JL \& Baxter RC (1986) Insulin-like growth factor-binding protein from human plasma. Purification and characterization. Journal of Biological Chemistry 261, 8754-8760.

Miura Y, Kato H \& Noguchi T (1992) Effects of dietary proteins on insulin-like growth factor-I (IGF-I) messenger ribonucleic acid content in rat liver. British Journal of Nutrition 67, 257-265.

Moats-Staats BM, Brady JL Jr, Underwood LE \& D'Ercole AJ (1989) Dietary protein restriction in artificially reared neonatal rats causes a reduction of insulin-like growth factor-1 gene expression. Endocrinology 125, 2368-2374.

Mohan S, Bautista CM, Wergedal J \& Baylink DJ (1989) Isolation of an inhibitory insulin-like growth factor (IGF) binding protein from bone cell-conditioned medium: a potential local regulator of IGF action. Proceedings of the National Academy of Sciences USA 86, 8338-8342.

Murphy LJ (1991) The uterine insulin-like growth factor system. In Modern Concepts of Insulin-like Growth Factors, pp. 275 284 [EM Spencer, editor]. New York, NY: Elsevier Science Publishing Co., Inc.

Murphy LJ \& Friesen HG (1988) Differential effects of estrogen and growth hormone on uterine and hepatic insulin-like growth factor I gene expression in the ovariectomized hypophysectomized rat. Endocrinology 122, 325-332.

Murphy LJ, Seneviratne C, Moreira P \& Reid RE (1991) Enhanced expression of insulin-like growth factor-binding protein-I in the fasted rat: the effects of insulin and growth hormone administration. Endocrinology 128, 689-696.

Nam TJ, Noguchi T, Funabiki R, Kato H, Miura Y \& Naito H (1990) Correlation between the urinary excretion of acidsoluble peptides, fractional synthesis rate of whole body proteins, and plasma immunoreactive insulin-like growth factor-1/somato-medin $C$ concentration in the rat. British Journal of Nutrition 63, 515-520.

Nestler JE (1993) Regulation of the aromatase activity of human placental cytotrophoblast by insulin, insulin-like growth factor-I and -II. Journal of Steroid Biochemistry and Molecular Biology 44, 449-457.

Orlowski CC, Brown AL, Ooi GT, Yang YW-H, Tseng LY-H \& Rechler MM (1990) Tissue, developmental and metabolic regulation of messenger ribonucleic acid encoding a rat insulinlike growth factor-binding protein. Endocrinology 126, 644-652.

Prewitt TE, D'Ercole AJ, Switzer BR \& Van Wyk JJ (1982) Relationship of serum immunoreactive somatomedin-C to dietary protein and energy in growing rats. Journal of Nutrition 112, 144-150.
Sato F, Ouchi Y, Masuyama A, Nakamura T, Hosoi T, Okamoto Y, Sasaki N, Shiraki M \& Orimo H (1993) Effects of estrogen replacement on insulin-like growth factor I concentrations in serum and bone tissue and on interleukin 1 secretion from spleen macrophages in oophorectomized rats. Calcified Tissue International 53, 111-116.

Shimasaki S, Uchiyama F, Shimonaka M \& Ling N (1990) Molecular cloning of the cDNAs encoding a novel insulin-like growth factor binding protein from rat and human. Molecular Endocrinology 4, 1451-1458.

Shimasaki S, Gao L, Shimonaka M \& Ling N (1991a) Isolation and molecular cloning of insulin-like growth factor-binding protein-6. Molecular Endocrinology 5, 938-948.

Shimasaki S, Shimonaka M, Zhang H-P \& Ling N (1991b) Identification of five different insulin-like growth factor binding-proteins (IGFBPs) from adult rat serum and molecular cloning of a novel IGFBP-5 in rat plasma. Journal of Biological Chemistry 266, 10646-10653.

Snedecor GW \& Cochran WG (1967) One-way classifications. Analysis of variance. Inspection of all differences between pairs of means. In Statistical Methods, 6th ed., pp. 271-273. Ames, IA: Iowa State University Press.

Takahashi S, Kajikawa M, Umezawa T, Takahashi S-I, Kato H, Miura Y, Nam TJ, Noguchi T \& Naito H (1990) Effect of dietary proteins on the plasma immunoreactive insulin-like growth factor-1/somatomedin c concentration in the rat. British Journal of Nutrition 63, 521-534.

Takenaka A, Hirosawa M, Mori M, Yamada S, Miura Y, Kato H, Takahashi S-I \& Noguchi T (1993) Effect of protein nutrition on the mRNA content of insulin-like growth factor-binding protein-1 in liver and kidney of rats. British Journal of Nutrition 69, 73-82.

Takenaka A, Miura Y, Mori M, Hirosawa M, Kato H \& Noguchi $\mathrm{T}$ (1991) Distribution of messenger RNAs of insulin-like growth factor (IGF)-binding proteins- 1 and -3 between parenchymal and nonparenchymal cells in rat liver. Agricultural and Biological Chemsitry 55, 1191-1193.

Takenaka A, Mori M, Yamada S, Ohgane J, Takahashi S-I \& Noguchi T (1996) Nutritional regulation of gene expression of insulin-like growth factor-binding proteins and the acid-labile subunit in various tissues of rats. Journal of Endocrinology 150 , $33-41$.

Thissen J-P, Ketelslegers J-M \& Underwood LE (1994) Nutritional regulation of the insulin-like growth factors. Endocrine Reviews 15, 80-101.

Thissen J-P, Triest S, Moats-Staats BM, Underwood LE, Mauerhoff T, Maiter D \& Ketelslegers JM (1991a) Evidence that pretranslational and translational defects decrease serum IGF-I concentrations during dietary protein restriction. Endocrinology 129, 429-435.

Thissen J-P, Underwood LE, Maiter D, Maes M, Clemmons DR \& Ketelslegers J-M (1991b) Failure of insulin-like growth factor-I (IGF-I) infusion to promote growth in protein-restricted rats despite normalization of serum IGF-I concentrations. Endocrinology 128, 885-890.

Umezawa T, Ohsawa Y, Miura Y, Kato H \& Noguchi T (1991) Effect of protein deprivation on insulin-like growth factorbinding proteins in rats. British Journal of Nutrition 66, 105116.

Vinik A, Pittenger G, Rafaeloff R \& Rosenberg L (1993) Factors controlling pancreatic islet neogenesis. Tumor Biology 14, 184200. 